\title{
Universality of Mic romolar-Level Cell-Based Hydrogen Peroxide Generation during Direct Cold Atmospheric Plasma Treatment
}

\author{
Dayun Yan, a,t,* Li Lin, ${ }^{\mathrm{a}, \dagger}$ Wenjun Xu, ${ }^{\mathrm{b}}$ Niku Nourmohammadi, ${ }^{\mathrm{c}}$ Jonathan $\mathrm{H}$. \\ Sherman, ${ }^{\mathrm{d}}$ \& Michael Keidara,* \\ aDepartment of Mechanical and Aerospace Engineering, The George Washington University, \\ Washington, D.C. 20052; 'State Key Laboratory of Electrical Insulation and Power Equipment, \\ Xi'an Jiaotong University, Xi'an, 710049, China; 'School of Medicine and Health Sciences, The \\ George Washington University, Washington, D.C. 20037; 'Neurological Surgery, The George \\ Washington University, Washington, D.C. 20037 \\ *Address all correspondence to: Dayun Yan, Department of Mechanical and Aerospace Engineering, The George Wash- \\ ington University, Science and Engineering Hall, 800 22nd Street, NW, Washington, D.C. 20052; Tel.: 202-994-6929; \\ Fax: 202-994-0127, E-mail: ydy2012@gwmail.gwu.edu or Michael Keidar, Department of Mechanical and Aerospace \\ Engineering, The George Washington University, Science and Engineering Hall, 800 22nd Street N.W., Washington, \\ D.C. 20052; Tel.: 202-994-6929; Fax: 202-994-0127, E-mail: keidar@gwu.edu
}

$\dagger$ These authors contributed equally to this work.

\begin{abstract}
Understanding the interaction between cold atmospheric plasma (CAP) and cells is a critical challenge in plasma medicine. CAP has shown promising application for cancer treatment. To date, dozens of cancer cells have been selectively killed during in vitro studies, and CAP-originated reactive species have been regarded to be the primary factor causing cancer cell death. In the past, we investigated hydrogen peroxide $\left(\mathrm{H}_{2} \mathrm{O}_{2}\right)$ generation at the micromolar level using two CAP-treated cancer cell lines. In this study, we further demonstrate the universality of such strong cell-based $\mathrm{H}_{2} \mathrm{O}_{2}$ generation in eight cancer cell lines. Nearly all lines showed capacity to generate a micromolar level of $\mathrm{H}_{2} \mathrm{O}_{2}$ during 1 min of CAP treatment when discharge voltage (peak value) was $>3.30 \mathrm{kV}$. Generally, higher discharge voltage corresponds to stronger cell-based $\mathrm{H}_{2} \mathrm{O}_{2}$ generation, although some cell lines produce maximum $\mathrm{H}_{2} \mathrm{O}_{2}$ generation at relatively low discharge voltage. Cell-based $\mathrm{H}_{2} \mathrm{O}_{2}$ generation may involve interaction between cancer cells and reactive oxygen species in CAP. The CAP optical emission spectrum demonstrates a significant increase in singlet oxygen $(\mathrm{O})$ and hydroxyl $(\mathrm{OH})$ radicals in CAP when discharge voltage is $>3.30 \mathrm{kV}$. This study demonstrates the universality of cell-based $\mathrm{H}_{2} \mathrm{O}_{2}$ generation that has not been considered in previous studies.
\end{abstract}

KEY WORDS: cold plasma, plasma medicine, cancer treatment, reactive oxygen species, $\mathrm{H}_{2} \mathrm{O}_{2}$

\section{INTRODUCTION}

During the past decade, cold atmospheric plasma (CAP) has presented promising application for many branches of medicine, including cancer treatment, ${ }^{1,2}$ sterilization, ${ }^{3}$ and wound healing. ${ }^{4}$ Abundant reactive species including reactive oxygen species (ROS) and reactive nitrogen species (RNS) in CAP have been regarded to be main factors for interaction between CAP and cells, particularly, cancer cells. ${ }^{5,6}$ To date, understanding such an interaction has been mainly limited to the belief that cells have a passive role during CAP treatment. ${ }^{7}$ The specific dose of CAP-originated ROS and RNS affects cel- 
lular function through complex cellular pathways. ${ }^{8}$ These reactive species finally trigger cell death (mainly apoptosis) in cancer cells in vitro. ${ }^{9}$

Recently, we demonstrated that breast cancer cells and pancreatic adenocarcinoma cells could generate a micromolar level of $\mathrm{H}_{2} \mathrm{O}_{2}$ during CAP treatment. ${ }^{10}$ Such measurement was performed by comparing between CAP treatment on the medium and cancer cells immersed in the medium. ${ }^{10}$ We found that $\mathrm{H}_{2} \mathrm{O}_{2}$ generation in medium without cancer cells was noticeably weaker than that in medium with cancer cells. ${ }^{10}$ To the best of our knowledge, this is the first evidence showing that cancer cells play an active part during CAP treatment by generating toxic $\mathrm{H}_{2} \mathrm{O}_{2}$ in their extracellular environment. ${ }^{10}$ However, whether such cell-based $\mathrm{H}_{2} \mathrm{O}_{2}$ generation is a general cellular response to CAP treatment is still unknown.

Here, we demonstrate the universality of cell-based $\mathrm{H}_{2} \mathrm{O}_{2}$ generation as a commonly existing cellular response to CAP treatment in eight cancer cell lines. All lines have been widely used in many plasma medicine laboratories. We show discharge voltage to be an important parameter for modulating cell-based $\mathrm{H}_{2} \mathrm{O}_{2}$ generation. Optical emission spectrum (OES) measurement and chemical simulation method provide clues for understanding such cellular response.

\section{METHODS AND MATERIALS}

Several labs at The George Washington University donated cell lines. All cells were purchased from the American Type Culture Collection. Human pancreatic adenocarcinoma (PA-TU-8988T) and human lung carcinoma (A549) cell lines were provided by Dr. Ferid Murad's lab. Human breast cancer cell lines (MDA-MB-231 and MCF-7) were provided by Dr. Lijie Grace Zhang's lab. Human colorectal carcinoma (HCT116), human cervical adenocarcinoma (HeLa), and human bone osteosarcoma (U-2 OS) cell lines were provided by Dr. Wenge Zhu's lab. A murine melanoma cell line (B16F10) was provided by Dr. Eduardo Sotomayor's lab. The medium used in the culture of B16F10 cells was comprised of Roswell Park Memorial Institute-1640 supplemented with 10\% fetal bovine serum (FBS) (Atlanta Biologicals, S11150; Flowery Branch, GA) and 1\% (v/v) penicillin-streptomycin solution (Life Technologies Corporation, 15140122; Carlsbad, CA). All other cells were cultured in Dulbecco Modified Eagle Medium (DMEM) (Life Technologies Corporation, 11965-118) supplemented with 10\% (v/v) FBS and 1\% (v/v) penicillinstreptomycin solution. For each experiment, $100 \mu \mathrm{L}$ of $3 \times 10^{4}$ cancer cells were seeded in one well of a 96-well plate $1 \mathrm{~d}$ before CAP treatment. All cells were cultured for $24 \mathrm{~h}$ under standard culture conditions (humidified, $37^{\circ} \mathrm{C}, 5 \% \mathrm{CO}_{2}$ environment).

The CAP jet generator, which used helium as the carrying gas, has already been used in a series of previous studies, ${ }^{11,12}$ and its detailed description is described elsewhere. ${ }^{11,12}$ Here, we offer a short introduction [Fig. 1(a)]. CAP was formed as a result of discharge between central anode and ring-grounded cathode and then ejected out of a quartz tube driven by helium flow at a rate of $1.53 \mathrm{~L} / \mathrm{min}$. Discharge was driven by alternating-current high voltage $(>3 \mathrm{kV}$ peak value), with a frequency of $12.6 \mathrm{kHz}$. In the gas phase, CAP was mainly comprised of ROS $(\mathrm{OH}, \mathrm{O})$, RNS $\left(\mathrm{NO}, \mathrm{N}_{2}^{+}\right)$, and helium. ${ }^{11,12}$ The gap between the bottom of the 96-well plate and bottom edge of the quartz tube was $2.8 \mathrm{~cm}$. During CAP treatment, 

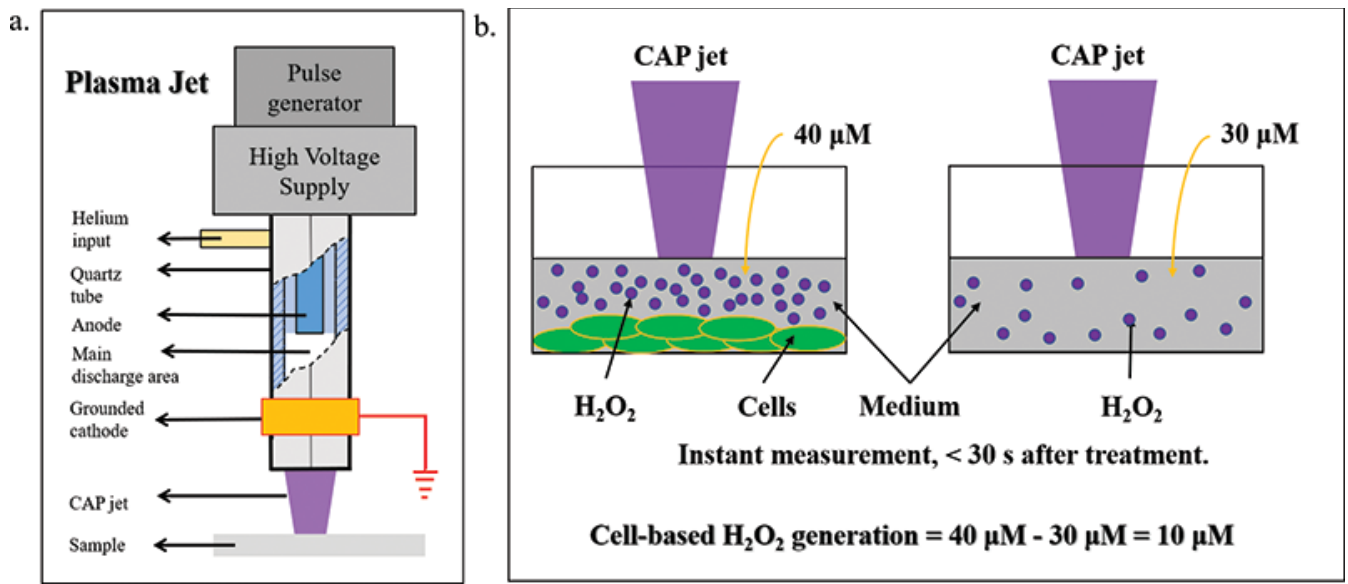

FIG. 1: Experimental setup and cell-based $\mathrm{H}_{2} \mathrm{O}_{2}$ generation measurement. (a) Schematic illustration of CAP jet. (b) Strategy to measure cell-based $\mathrm{H}_{2} \mathrm{O}_{2}$ generation during CAP treatment. We use one example to illustrate calculation for cell-based $\mathrm{H}_{2} \mathrm{O}_{2}$ generation on the basis of $\mathrm{H}_{2} \mathrm{O}_{2}$ concentration measurement in different cases. As examples, we used 40 and $30 \mu \mathrm{M} \mathrm{H}_{2} \mathrm{O}_{2}$.

$100 \mu \mathrm{L} /$ well of medium was used to protect cells from dehydration from helium flow. The medium used during CAP treatment was a mix of $1 \%(\mathrm{v} / \mathrm{v})$ penicillin-streptomycin solution with standard DMEM. We renewed the medium before performing CAP treatment.

For this study, we used the same strategy as that reported in a previous study, ${ }^{10}$ but we show a short introduction to the research strategy in Fig. 1(b). We used 1 min of CAP jet treatment to vertically treat cells grown in a 96-well plate or $100 \mu \mathrm{L} /$ well of DMEM without cells in a 96-well plate. Cells were immersed in $100 \mu \mathrm{L} /$ well of DMEM. We compared $\mathrm{H}_{2} \mathrm{O}_{2}$ generation in DMEM with cells against $\mathrm{H}_{2} \mathrm{O}_{2}$ generation in medium without cells, immediately $(<30 \mathrm{~s})$ after CAP treatment. The difference between the two $\mathrm{H}_{2} \mathrm{O}_{2}$ concentrations revealed whether cell-based $\mathrm{H}_{2} \mathrm{O}_{2}$ generation occurred. When the difference was positive, we expected extra $\mathrm{H}_{2} \mathrm{O}_{2}$ generation to occur by CAP-treated cells. When the difference was negative, cell-based $\mathrm{H}_{2} \mathrm{O}_{2}$ generation was not strong enough to counteract $\mathrm{H}_{2} \mathrm{O}_{2}$ consumption by cells. On the basis of this strategy, we obtained cell-based $\mathrm{H}_{2} \mathrm{O}_{2}$ generation of eight cell lines during CAP treatment. We measured the $\mathrm{H}_{2} \mathrm{O}_{2}$ assay in DMEM using the Fluorimetric Hydrogen Peroxide Assay Kit (Sigma-Aldrich, MAK1651KT; St. Louis, MO). Fluorescence was measured with an H1 microplate reader (Hybrid Technology; Winooski, VT) at 540/590 nm. Reactive species concentration was finally obtained by comparing measured fluorescence with the standard curve. All experiments were independently repeated at least three times.

\section{RESULTS AND DISC USSION}

As we revealed in previous study, cell-based $\mathrm{H}_{2} \mathrm{O}_{2}$ generation is typically an instant cellular response to CAP treatment. ${ }^{10}$ Cell-based $\mathrm{H}_{2} \mathrm{O}_{2}$ generation will be consumed by

Volume 8, Issue 4, 2018 
unknown factors in extracellular medium after as little as $10 \mathrm{~min} .{ }^{10}$ Moreover, the entire amount of $\mathrm{H}_{2} \mathrm{O}_{2}$ in the extracellular environment will be consumed by cancer cells in $\sim 3-4 \mathrm{~h}^{13}$ Thus, in this study, we also investigated cell-based $\mathrm{H}_{2} \mathrm{O}_{2}$ generation at $30 \mathrm{~s}$ after direct CAP treatment. Cell-based $\mathrm{H}_{2} \mathrm{O}_{2}$ generation is quantitated by comparing between $\mathrm{H}_{2} \mathrm{O}_{2}$ concentration of CAP-treated DMEM and $\mathrm{H}_{2} \mathrm{O}_{2}$ concentration of CAP-treated DMEM that was used to immerse cells during CAP treatment [Fig. 1(b)]. DMEM volume during CAP treatment was $100 \mu \mathrm{L}$. Output discharge voltages were set to $3.02,3.16,3.30,3.44,3.58$, and $3.72 \mathrm{kV}$.

Cell-based $\mathrm{H}_{2} \mathrm{O}_{2}$ generation is a universal cellular response of many cancer cells to CAP treatment. For all investigated cancer cell lines, cells generate micromolar-level $\mathrm{H}_{2} \mathrm{O}_{2}$ when discharge voltage is modulated to a suitable level (Fig. 2). Only A549 cells have very weak $\mathrm{H}_{2} \mathrm{O}_{2}$ generation when discharge voltage is $3.02 \mathrm{kV}$. With discharge voltage $>3.16 \mathrm{kV}$, cell-based $\mathrm{H}_{2} \mathrm{O}_{2}$ generation can be observed in all cell lines. For the

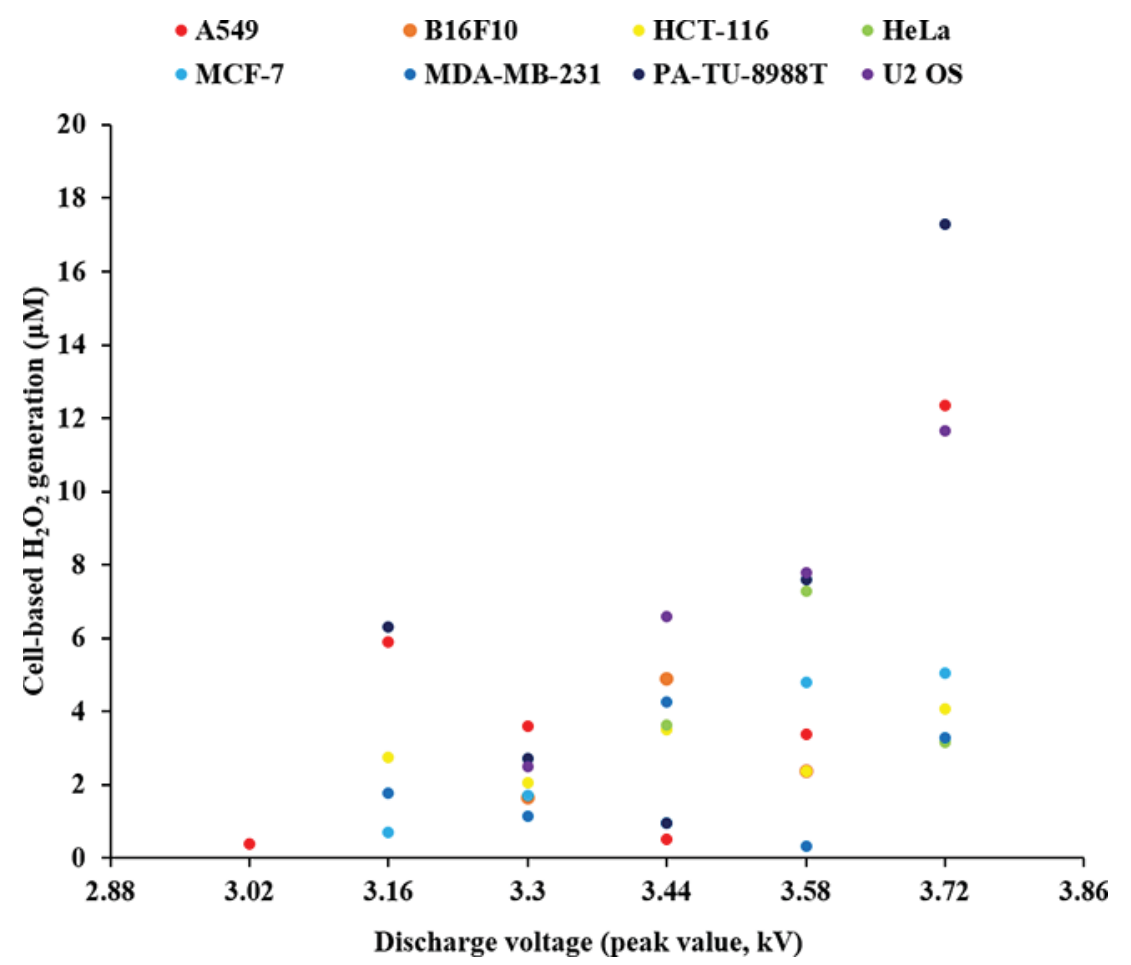

FIG. 2: Cell-based $\mathrm{H}_{2} \mathrm{O}_{2}$ generation commonly exists in many cancer cell lines; positive cell-based $\mathrm{H}_{2} \mathrm{O}_{2}$ generation is shown here. A549, Lung carcinoma; B16F10, melanoma; HCT116, colorectal carcinoma; HeLa, cervical adenocarcinoma; MDA-MB-231 and MCF-7, breast cancer; PA-TU8988T, pancreatic adenocarcinoma; U-2 OS, bone osteosarcoma. Lightest-colored dot with darker outline in fifth column $(3.58 \mathrm{kV})$ is due to overlap between yellow and orange dots in that column. At least seven cell lines have observable $\mathrm{H}_{2} \mathrm{O}_{2}$ generation with discharge voltage $>3.3 \mathrm{kV}$. Results are shown as means of independently repeated results. 
HeLa cell line, cell-based $\mathrm{H}_{2} \mathrm{O}_{2}$ generation can be observed only with discharge voltage $>3.44 \mathrm{kV}$. Generally, noticeable cell-based $\mathrm{H}_{2} \mathrm{O}_{2}$ generation tends to occur when discharge voltage is adequately large $(>3.16 \mathrm{kV})$. However, cell-based $\mathrm{H}_{2} \mathrm{O}_{2}$ generation is not linearly proportional to discharge voltage. Only the U-2 OS cell line followed this trend during discharge voltage from 3.30 to $3.72 \mathrm{kV}$. For A549, HCT116, MCF-7, PA-TU-8988T, and U-2 OS cell lines, maximum cell-based $\mathrm{H}_{2} \mathrm{O}_{2}$ generation was observed when discharge voltage reaches a maximum of $3.72 \mathrm{kV}$. For MDA-MB-231 and B16F10 cell lines, maximum cell-based $\mathrm{H}_{2} \mathrm{O}_{2}$ generation occurs when discharge voltage is $3.44 \mathrm{kV}$. For A549 and PA-TU-8988T cell lines, cell-based $\mathrm{H}_{2} \mathrm{O}_{2}$ generation is inversely proportional to discharge voltage of 3.16 to $3.44 \mathrm{kV}$. For B16F10 and HeLa cell lines, cell-based $\mathrm{H}_{2} \mathrm{O}_{2}$ generation is also inversely proportional to discharge voltage of 3.58 to $3.72 \mathrm{kV}$. In contrast, cell-based $\mathrm{H}_{2} \mathrm{O}_{2}$ generation of all other cell lines is proportional to discharge voltage of 3.58 to $3.72 \mathrm{kV}$. The underlying mechanism for these differences and trends remains unknown.

This study confirms a universal cellular response to CAP treatment that to the best of our knowledge has not been noted before in plasma medicine. As revealed in our previous report, cell-based $\mathrm{H}_{2} \mathrm{O}_{2}$ generation will not occur when cancer cells are affected by CAP-stimulated medium (PSM). The central reactive species in PSM should be mainly long lived, rather than short lived. Short-lived ROS in CAP such as superoxide $\left(\mathrm{O}_{2}^{-}\right)$may be involved in cell-based $\mathrm{H}_{2} \mathrm{O}_{2}$ generation through a dismutation reaction catalyzed by extracellular catalase (Ex-SOD, SOD3). ${ }^{14-16}$ And cancer cell lines in this study will not generate measurable $\mathrm{H}_{2} \mathrm{O}_{2}$ during the culture process.

The OES and chemical simulation were used to quantify the change in CAP jet when discharge voltage increased from 3.02 to $3.72 \mathrm{kV}$. The OES was measured using a Stellarnet spectrometer in a range of 191 to $851 \mathrm{~nm}$. As an example, a typical OES is shown in Fig. 3. The spectrum shows that the jet's purple color is a result of excited $\mathrm{N}_{2}$ and $\mathrm{N}_{2}^{+}$emission. The intensity ratio of 391.44 and $337.13 \mathrm{~nm}$ is usually used for electron temperature calculation. ${ }^{17} \mathrm{OH}(309.9 \mathrm{~nm})$ and $\mathrm{NO}(311.24 \mathrm{~nm})$ peaks are commonly found in the ultraviolet range, whereas 777.194-nm emission is the only O emission captured in the optical range. The 706.519-nm peak implies the existence of triplet helium.

Chemical simulation was based on selected collisions from previous literature ${ }^{18-21}$ and the Boltzmann solver BOLSIG+ (with the Trinity Library; Dublin, UK). ${ }^{22}$ In the simulation, initial densities of all species were $10^{6} \mathrm{~cm}^{-3}$ and we expected that electron density was $10^{12} \mathrm{~cm}^{-3}$. Helium, $\mathrm{H}_{2} \mathrm{O}, \mathrm{N}_{2}$, and $\mathrm{O}_{2}$ were determined by a mole fraction of $\mathrm{He}: \mathrm{H}_{2} \mathrm{O}: \mathrm{N}_{2}: \mathrm{O}_{2}=0.99: 0.0001: 0.0079: 0.002$ at $1 \mathrm{~atm}$ room temperature. With $d t=10 \mathrm{ps,}$ densities were evolved by rate equation $\partial n_{i} / \partial t=\Sigma_{j} k_{j} \Pi n_{j l}$, where $n_{i}$ is the density of the $i$ th species; $k_{j}$ is the rate coefficient of the $j$ th reaction, found either in the literature or calculated by BOLSIG+; and $n_{j l}$ is the density of the $l$ th reactant in the $j$ th reaction. In the rate equations, most electron-involved reaction rate coefficients were functions of electron temperature that was related to reduced electric field $E / N$, determined by discharge voltage. Therefore, the simulation resulted in different final-species densities, converged at $\sim 0.1 \mathrm{~ms}$, and corresponding to different discharge voltages.

Volume 8, Issue 4, 2018 


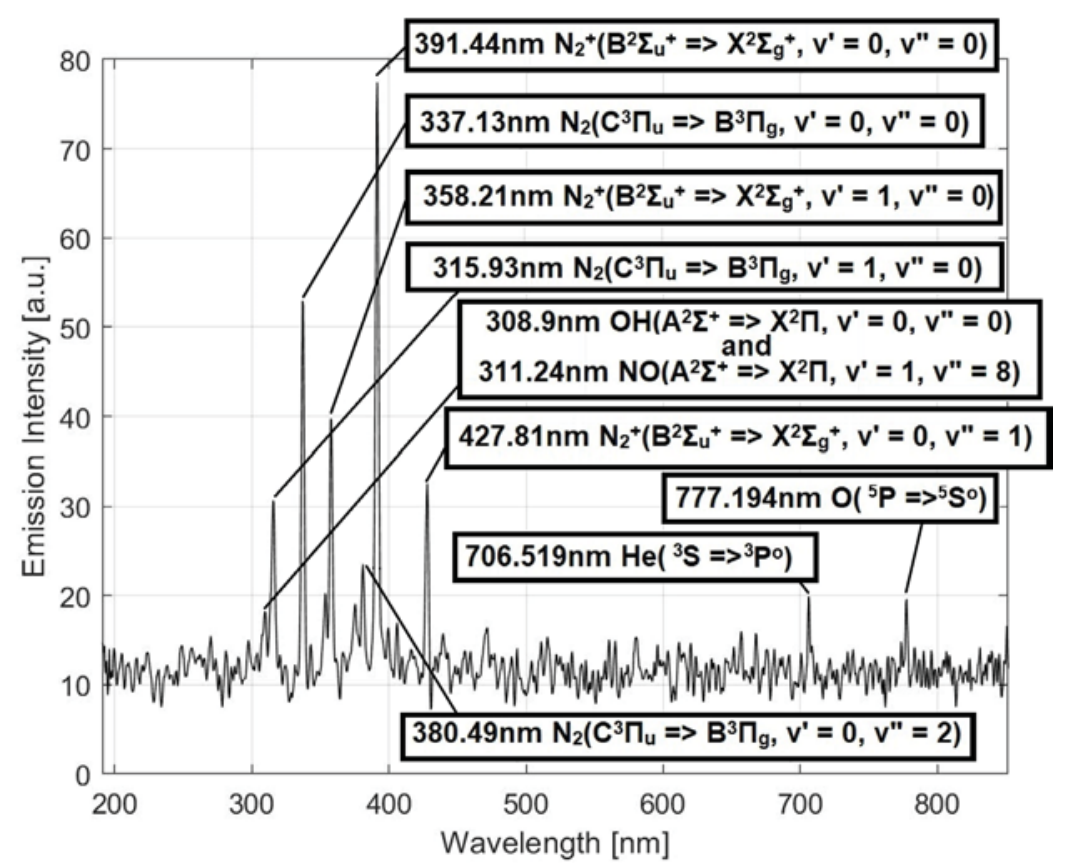

FIG. 3: CAP jet OES at discharge voltage of $3.02 \mathrm{kV}$

To investigate the effect of discharge voltage, the summation of all $\mathrm{O}$ intensities is summarized in Fig. 4(a) and that of OH is shown in Fig. 4(c). These OES intensities stay low with discharge voltage $<3.3 \mathrm{kV}$. Between 3.3 and $3.55 \mathrm{kV}$, intensities augment and slightly decrease at a further increment of discharge. For simulated $\mathrm{O}$ and $\mathrm{OH}$ densities, assuming 2-mm ionization wavefront length times, the electric field is calculated by $E / N$ swept in BOLSIG + . The discharge voltage axis is thus calculated and indicates a similar pattern for $\mathrm{O}$ and $\mathrm{OH}$ densities, as shown in Fig. 4(b) and (d). Discharge voltage directly determines electric field that accelerates electrons and leads to an ionization wave. ${ }^{23}$ The observed agreement proves that the sudden boost in intensities at $3.4-3.55 \mathrm{kV}$ may be due to density increments, although not all $\mathrm{O}$ and $\mathrm{OH}$ are excited. We also note that maximum intensity of $\mathrm{O}$ is lower than that of $\mathrm{OH}$, whereas maximum density of $\mathrm{O}$ is higher than that of $\mathrm{OH}$. Such a difference results from only one peak of $\mathrm{O}$ at $706.519 \mathrm{~nm}$, which is a minor part of $\mathrm{O}$ emission. Nevertheless, patterns of intensities and densities versus discharge voltage are still accurate and informative.

In addition, densities of $\mathrm{H}, \mathrm{O}_{2}^{-}$, and $\mathrm{H}_{2} \mathrm{O}_{2}$ in the simulation also have a similar relationship with discharge voltage, as shown in Fig. 5. Other species are also included, but because they have minor roles, their densities are too low to be observed and overlap at the bottom of the figure. According to the simulation, the density of $\mathrm{O}$ is nearly twice larger than that of OH. Short-lived ROS in CAP may trigger cell-based $\mathrm{H}_{2} \mathrm{O}_{2}$ generation. $\mathrm{O}$ may combine with two electrons $\left(\mathrm{e}^{-}\right)$to form $\mathrm{O}_{2}^{-}$, which further 
(a)
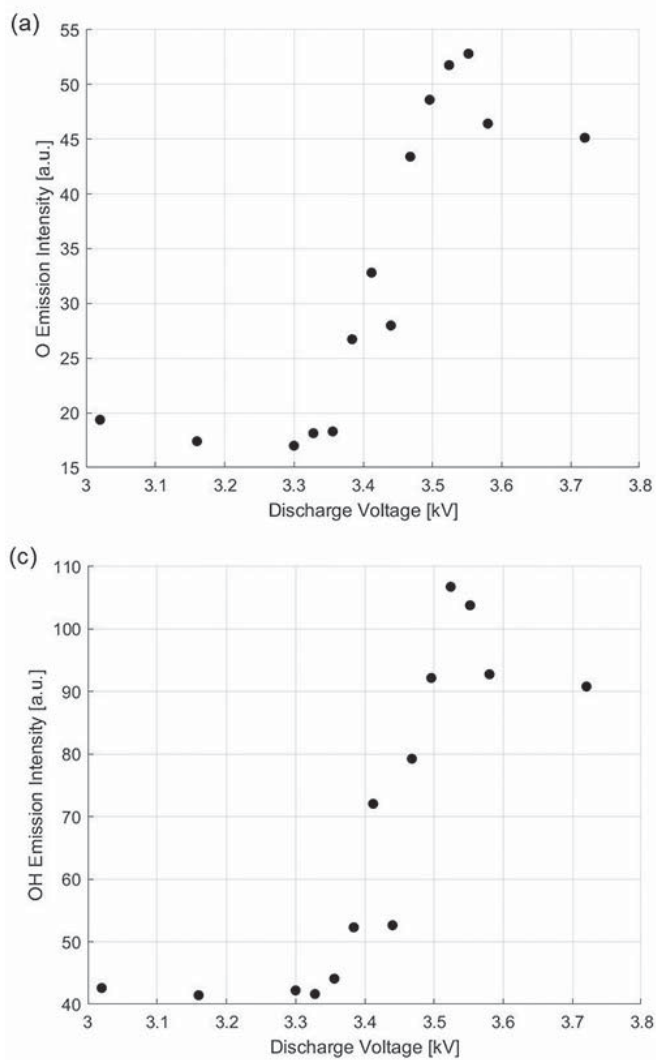

(b)

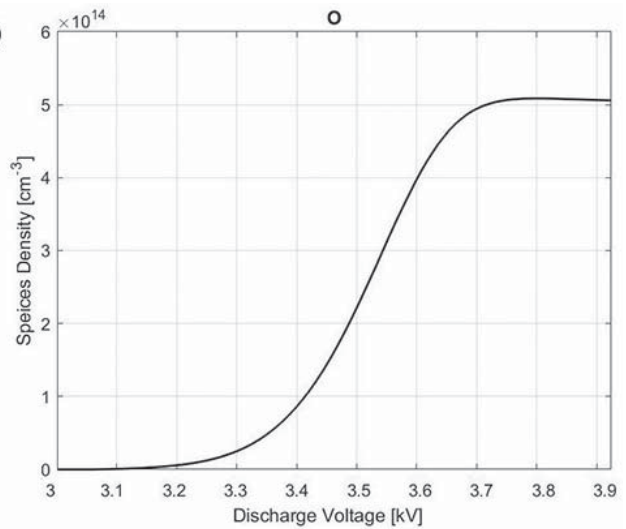

(d)

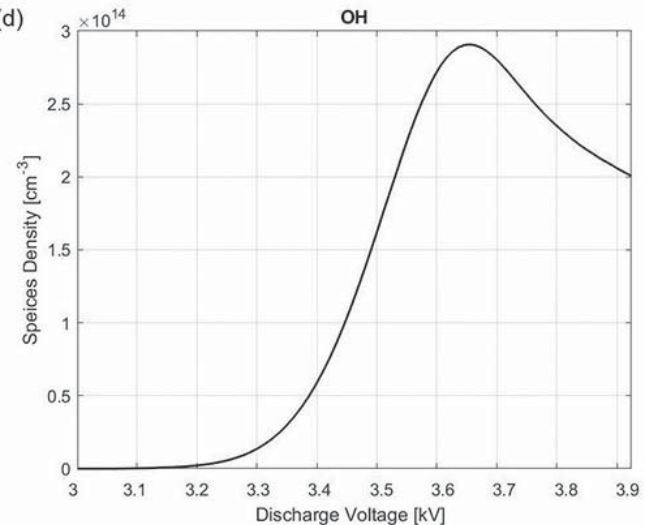

FIG. 4: OES Measurement and simulations. Optical emission intensity was measured using an optical spectrometer. We performed density simulation using the method described in the text. (a) Optical emission intensities of $777.194 \mathrm{~nm} \mathrm{O}\left({ }^{5} \mathrm{P} \rightarrow{ }^{5} \mathrm{~S}^{\mathrm{O}}\right)$; (b) simulation density of $\mathrm{O}$; (c) summation of three optical emission intensities of $\mathrm{OH}\left(\mathrm{A}^{2} \Sigma^{+} \rightarrow \mathrm{X}^{2} \Pi\right)$, including $282.9 \mathrm{~nm}\left(\mathrm{v}^{\prime}=1, \mathrm{v}^{\prime \prime}=2\right)$, $296.24 \mathrm{~nm}\left(\mathrm{v}^{\prime}=3, \mathrm{v}^{\prime \prime}=2\right)$, and $308.9 \mathrm{~nm}\left(\mathrm{v}^{\prime}=0, \mathrm{v}^{\prime \prime}=0\right)$; (d) simulation density of $\mathrm{OH}$

triggers cell-based $\mathrm{H}_{2} \mathrm{O}_{2}$ generation through the dismutation reaction catalyzed by extracellular superoxide dismutase on the cellular membrane. Noticeable cell-based $\mathrm{H}_{2} \mathrm{O}_{2}$ generation is observed with discharge voltage $>3.16 \mathrm{kV}$, during which the increase in $\mathrm{O}$ occurs.

Cell-based $\mathrm{H}_{2} \mathrm{O}_{2}$ generation provides a strategy to enhance anticancer effects of CAP treatment. Of the eight cancer cell lines, PA-TU-8988T generates the greatest $\mathrm{H}_{2} \mathrm{O}_{2}$ $(17.3 \mu \mathrm{M})$ when discharge voltage is $3.72 \mathrm{kV} . \mathrm{H}_{2} \mathrm{O}_{2}$ is an important cellular signaling molecule, involving a series of important biological processes, including redox balance, cellular membrane damage, DNA damage, apoptosis, and immune activation. ${ }^{17} \mathrm{H}_{2} \mathrm{O}_{2}$ is also an essential signaling molecule in cancer biology. ${ }^{24,25}$ For CAP treatment application in vivo, cell-based $\mathrm{H}_{2} \mathrm{O}_{2}$ generation may also exist. Cell-based $\mathrm{H}_{2} \mathrm{O}_{2}$ generation may involve a series of physiological responses to CAP treatment at tissue levels.

Volume 8, Issue 4, 2018 


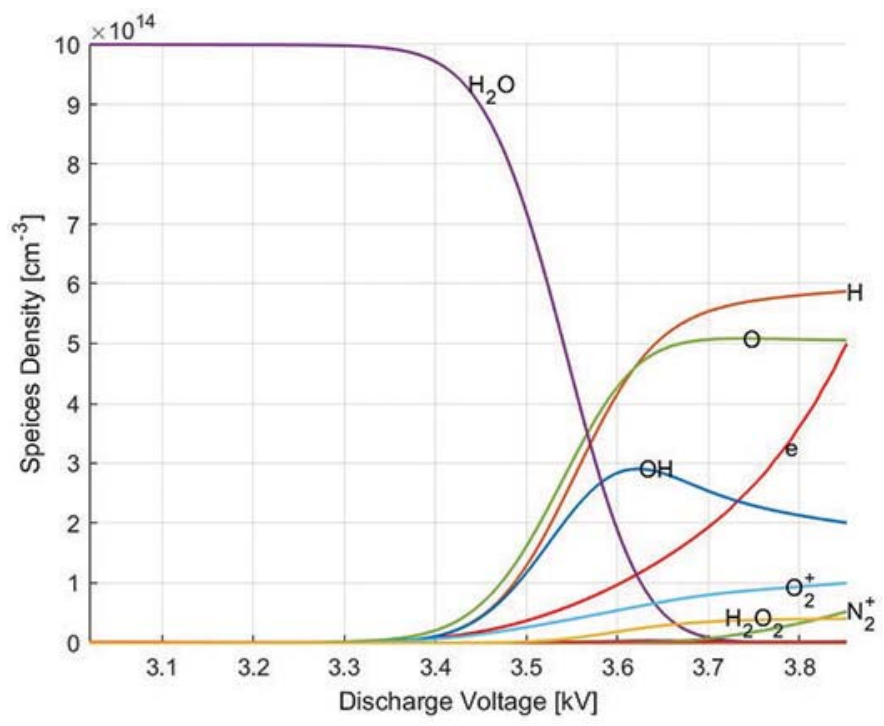

FIG. 5: Final densities of all species considered in the simulation

\section{CONCLUSIONS}

Cell-based $\mathrm{H}_{2} \mathrm{O}_{2}$ generation during CAP treatment is a general basic cellular response of cancer cells to direct CAP treatment. This study may facilitate understanding of observed cellular response to CAP treatment from a new perspective. We demonstrate that cancer cells not only play a passive part in plasma medicine but also actively affect neighboring cells by generating micromolar levels of $\mathrm{H}_{2} \mathrm{O}_{2}$. Discharge voltage is a key factor in regulating cell-based $\mathrm{H}_{2} \mathrm{O}_{2}$ generation, and modest discharge voltage can maximize cell-based $\mathrm{H}_{2} \mathrm{O}_{2}$ generation.

\section{ACKNOWHGMENT}

This work was supported by National Science Foundation Grant No. 1465061.

\section{REFERENCES}

1. Keidar M. A prospectus on innovations in the plasma treatment of cancer. Phys Plasmas. 2018;25(8):083504.

2. Keidar M, Yan D, Beilis I, Trink B, Sherman J. Plasmas for treating cancer: Opportunities for adaptive and self-adaptive approaches. Trends Biotechnol. 2018;36(6):586-93.

3. Laroussi M. Low-temperature plasma jet for biomedical applications: A review. IEEE Trans Plasma Sci. 2015;43(3):703-12.

4. Fridman G, Friedman G, Gutsol A, Shekhter A, Vasilets V, Fridman A. Applied plasma medicine. Plasma Proc Polym. 2008;5(6):503-33.

5. Graves D. The emerging role of reactive oxygen and nitrogen species in redox biology and some implications for plasma applications to medicine and biology. J Phys D Appl Phys. 2012;45:263001-42. 
Micromolar-Level Cell-Based $\mathrm{H}_{2} \mathrm{O}_{2}$ Generation during CAP Treatment

6. Yan D, Sherman J, Keidar M. Cold atmospheric plasma, a novel promising anti-cancer treatment modality. Oncotarget. 2017;8(9):15977.

7. Keidar M, Shashurin A, Volotskova O, Ann M, Srinivasan P, Sandler A, Trink B. Cold atmospheric plasma in cancer therapy. Phys Plasmas. 2013;20(5):057101.

8. Ishaq M, Evans M, Ostrikov K. Effect of atmospheric gas plasmas on cancer cell signaling. Int J Cancer. 2014;134(7):1517-28.

9. Yan D, Talbot A, Nourmohammadi N, Sherman J, Cheng X, Keidar M. Toward understanding the selective anticancer capacity of cold atmospheric plasma: A model based on aquaporins. Biointerphases. 2015;10(4):40801.

10. Yan D, Cui H, Zhu W, Talbot A, Zhang L, Sherman J, Keidar M. The strong cell-based hydrogen peroxide generation triggered by cold atmospheric plasma. Sci Rep. 2017;7(1):10831.

11. Shashurin A, Stepp M, Hawley T, Pal-Ghosh S, Brieda L, Bronnikov S, Jurjus R, Keidar M. Influence of cold plasma atmospheric jet on surface integrin expression of living cells. Plasma Proc Polym. 2010;7(3-4):294-300.

12. Yan D, Talbot A, Nourmohammadi N, Cheng X, Canady J, Sherman J, Keidar M. Principles of using cold atmospheric plasma stimulated media for cancer treatment. Sci Rep. 2015;5:18339.

13. Yan D, Cui H, Zhu W, Nourmohammadi N, Milberg J, Zhang L, Sherman J, Keidar M. The specific vulnerabilities of cancer cells to the cold atmospheric plasma-stimulated solutions. Sci Rep. 2017;7(1):4479.

14. Kalghatgi S, Kelly CM, Cerchar E, Torabi B, Alekseev O, Fridman A, Friedman G, Azizkhan-Clifford J. Effects of non-thermal plasma on mammalian cells. PLoS ONE. 2011;6(1):e16270.

15. Nozik-Grayck E, Suliman H, Piantadosi C. Extracellular superoxide dismutase. Int J Biochem Cell Biol. 2005;37(12):2466-71.

16. Ameziane-El-Hassani R, Schlumberger M, Dupuy C. NADPH oxidases: New actors in thyroid cancer? Nat Rev Endocrinol. 2016;12(8):485-94.

17. Veal E, Day A, Morgan B. Hydrogen peroxide sensing and signaling. Mol Cell. 2007;26(1):1-14.

18. Sakiyama Y, Graves D, Chang H, Shimizu T, Morfill G. Plasma chemistry model of surface microdischarge in humid air and dynamics of reactive neutral species. J Phys D Appl Phys. 2012;45(42):425201.

19. Kossyi IA, Yu Kostinsky A, Matveyev AA, Silakov VP. Kinetic scheme of the non-equlibrium discharge jn nitrogen-oxygen mixtures. Plasma Sources Sci Technol. 1992;1(3):207-20.

20. Golubovskii YB, Maiorov V, Behnke J, Behnke JF. Modelling of the homogeneous barrier discharge in helium at atmospheric pressure. J Phys D Appl Phys. 2003;36(1):39-49.

21. Norberg S, Johnsen E, Kushner M. Formation of reactive oxygen and nitrogen species by repetitive negatively pulsed helium atmospheric pressure plasma jets propagating into humid air. Plasma Sources Sci Technol. 2015;24(3):35026.

22. Hagelaar G, Pitchford L. Solving the Boltzmann equation to obtain electron transport coefficients and rate coefficients for fluid models. Plasma Sources Sci Technol. 2005;14(4):722-33.

23. Lu X, Naidis G, Laroussi M, Ostrikov K. Guided ionization waves theory and experiments. Phys Rep. 2018;540(3):123-66.

24. Szatrowski T, Nathan C. Production of large amounts of hydrogen peroxide by human tumor cells. Cancer Res. 1991;51(3):794-9.

25. Schmielau J, Finn O. Activated granulocytes and granulocyte-derived hydrogen peroxide are the underlying mechanism of suppression of T-cell function in advanced cancer patients. Cancer Res. 2001;61(12):4756-60.

Volume 8, Issue 4, 2018 
